\title{
Access to and quality of early childhood education and care in Greece
}

\author{
Yunanistan'da erken çocukluk eğitimi ve bakımına erişim ve kalite \\ Nektarios Stellakis ${ }^{1}$
}

\section{Article History}

Received : 08 January 2018

Revised : 23 January 2018

Accepted : 02 March 2018

Online : 03 March 2018

Article Type

Review Article

\section{Makale Geçmişi}

Geliş : :08 Ocak 2018

Düzeltme : 23 Ocak 2018

Kabul : 02 Mart 2018

Çevrimiçi : 03 Mart 2018

Makale Türü

Derleme Makale
Abstract: The paper discusses issues related to young children's access to public nurseries and kindergartens as well as examining issues concerning the quality of Early Childhood Education and Care (ECEC) in general and focused in Greece. The purpose of this paper is not only to highlight the various problems but also to contribute to dialogue for the upgrading and improvement of ECEC in Greece. This is why we pay much attention to official documents, especially those from International Organizations or from European Union.

Keywords: Early Childhood Education and Care, Quality, Access, International Quality Indicators, European Context

Öz: Bu makale küçük çocukların devlete ait kreşlere ve anasınıflarına erişimine yönelik bir tartışma sunmasının yanı sıra Erken Çocukluk Eğitimi ve Bakımında (EÇEB) kaliteyi genel bağlamda ve Yunanistan bağlamında ele almaktadır. Bu makalenin amacı yalnızca çeşitli sorunlara dikkate çekmekle kalmayıp aynı zamanda Yunanistan'daki EÇEB'nin daha iyi hale getirilmesi ve geliştirilmesine katkıda bulunmaktır. $\mathrm{Bu}$ nedenle resmî belgelere, özellikle Uluslararası Kuruluşlardan veya Avrupa Birliği tarafindan yayınlananlara çok dikkat ediyoruz.

Anahtar Kelimeler: Erken çocukluk eğitimi ve bakımı, kalite, erişim, uluslararası kalite göstergeleri, Avrupa bağlamı

\footnotetext{
${ }^{1}$ University of Patras, Department of Early Childhood Education, Greece, nekstel@upatras.gr
} 


\section{INTRODUCTION}

Numerous international studies and research data provide compelling arguments regarding how critical the period of childhood is (until age 8: General Comment No. 7, 2005), for physical and emotional health, education achievement, social integration and overall success and happiness in the life of a child (Sylva, Melhuish, Sammons, Siraj-Blatchford \& Taggart, 2010; Proulx \& Lye, 2016; Raikes \&Shaeffer, 2016).

One would expect the society or the state to give absolute priority to the provision of equal developmental opportunities for all children in order to offset the various inequalities and inequities, as well as to investments related to children, especially when we know that timely support during childhood proves to have multiple benefits not only for the children themselves, but for society as a whole (National Scientific Council on the Developing Child, 2007). The profound importance of early childhood has been recognized recently more than ever before. The new sustainable development agenda (United Nations, 2015), adopted by numerous countries worldwide amongst which Greece, has set a number of goals (Sustainable Development Goals - SDGs), including -for the first time explicitly- the early childhood development (SDG 4.2). At the same time, some of the greatest organizations join forces to urge greater investment in early childhood development (World Bank and UNICEF, 2016). World Organization for Early Childhood Education (OMEP) Declaration 2017 "appeals to governments to comply with the financial commitments related to the development and sustainability of ECCE, ensuring with urgency: to give priority and increase public spending on ECCE, to allocate the necessary resources for equity and quality in ECCE, and to ensure free and public ECCE, which guarantees the expansion of the rights of the most disadvantaged sectors.

Within this framework Early Childhood Education and Care (hereafter ECEC), which corresponds to Level 0 in UNESCO's International Standard Classification of Education (2011) and refers to the education of children prior to their entry into primary education (for a definition, see also: OECD, 2001), can only be at the centre of interest and constitute an absolute priority of every political, social and educational debate since it can not only contribute decisively to the school success and life course of each child (UNESCO 2010/2011; Vandekerckhove \& Peeters, 2016) but can also bring about beneficial results for the whole of society (OECD: Starting Strong, 2001, 2006, 2012;McCuaig, Akbari \& Bertrand, 2016; Van Belle, 2016; Working Group on Early Childhood Education and Care, 2015). 


\section{The importance of Early Childhood Education and Care}

Taking on the one hand as commonly accepted that: "Early Childhood Education and Care (ECEC) is of prime importance. It is the foundation for successful lifelong learning, but also for social integration, personal development and later employability" (European Commission, 2011), and on the other that "ECEC can offer the highest rates of return during the learning cycle of an individual's life, especially for the more vulnerable groups" (Council of the EU, 2006), and, finally, taking into account " the clear evidence that the 'investment' in very early childhood has incomparable benefits, not only for the receivers of the investment, in other words the children themselves, but more generally, for the societies in which they live and for the generations that will come after them too" (OMEP, 2012) (see also Gertler, Heckman, Pinto, Zanolini, Vermeersch, Walker, Chang, \& Grantham-McGregor, 2014; Lake, 2016; McCuaig, Akbari \& Bertrand, 2016; Yoshikawa, Weiland, Brooks-Gunn, Burchinal, Espinosa, Gormley, Ludwig, Magnuson, Phillips, \&Zaslow, 2013), we share fully the Council of the EU's recommendation (2011) for the "provision of universally available high quality ECEC".

In accordance to the above view, we strongly support the attainment of the UN Sustainable Development Goal 4.2 ("By 2030, ensure that all girls and boys have access to quality early childhood development, care and pre-primary education so that they are ready for primary education"), arguing that quality ECEC is both a goal and "a prerequisite for the kind of accelerated progress that will be required to achieve the SDGs - and ensure that no one is left behind" (Albright, Mundy, \& Beardmore, 2016: 23).

For all the above reasons, the issue of the quality of ECEC is extremely topical. However, the fact that not all programmes of early childhood education are equally effective should be taken seriously into consideration. Only those that can be characterised as high quality have longterm effects on personal, family and social development (OECD, 2010). As Penn aptly noted (2009: 7) in a report to the European Commission, "ECEC is a good investment only when it is high quality. Poor quality ECEC may do more harm than good especially for children who come from vulnerable social groups". This point of view seems to have been accepted by the Council of Europe (2010: 4) who judged that "participation in quality early childhood education and care, with specially trained staff and the suitable ratio of staff - children, produces positive results for all children and proves more beneficial for the more disadvantaged ones". Nevertheless, the issue remains of its adoption as a principle by the member-countries and its implementation in practice. Of course, the same issue is universal and does not concern only the EU as "despite the vast amount of evidence for the benefits of quality 
ECCE, countries as well as donor agencies do not make the necessary investments to effect change in early learning" (Albright, Mundy, \& Beardmore, 2016: 25), leaving too many children outside quality ECEC (UNICEF, 2012). However, improvements such as the increased enrolments in pre-primary education during the last years (Proulx \& Lye, 2016) should not be either overlooked or overestimated.

\section{(High) Quality Early Childhood Education and Care}

According to Proulx \& Lye (2016: 24), "access to quality ECE [...] can improve child outcomes and reduce inequalities in children's development and school readiness". In that case, the definition and conceptual elucidation of concepts such as "quality" and "highquality" is necessary. Although these concepts are difficult to define precisely, nevertheless the international bibliography provides a multitude of interpretations, perspectives and parameters. While we are familiar with a number of them (e.g. National Association for the Education of Young Children, 2005; OECD, 2006; CoRe, 2011), for the present report we preferred the following, firstly because they include plenty of criteria related to what has already been mentioned and secondly due to the clarity and the measurability of their criteria:

a) UNICEF (2008). The child care transition: A league table of early childhood education and care in economically advanced countries. Report Card 8. Florence: UNICEF Innocenti Research Centre.

b) Quality Targets in Services for Young Children. ECNC: European Commission Network on Childcare and Other Measures to Reconcile the Employment and Family Responsibilities of Men and Women Proposals for a Ten Year Action Programme (1996).

The first reference (UNICEF, 2008) includes 10 indicators: two are related to the policy framework, two relate to access to ECEC programmes, two concern the support environment and four are related to quality. (see Appendix I)

The second (European Commission Network on Childcare, 1996) is a lot more detailed and includes 40 targets, distributed across nine axes, as follows:

- Policy framework: 6 targets

- Financial targets: 4

- Targets for levels and types of services: 5

- Education: 5 targets

- Staff-child ratios: 4 targets

- Staff employment and training: 5 targets

- Environment and health: 5 targets

- Targets for parents and the community: 3 
- Performance targets: 4 (see Appendix II)

These two reference texts are linked to all the occasional recommendations of the European Committee after Barcelona (2002) and especially those contained in the texts: "Early childhood education and care: Providing our children with the best start for the world of tomorrow" (European Commission, 2011) and "Council Conclusions on early childhood education and care: Providing all our children with the best possible start for the world of tomorrow" (EU Council, 2011). In such a case, a picture can easily be formed of how a framework can be determined which, even if it does not define what quality in ECEC is, at least describes the conditions which make it attainable. Based on this framework, we will then endeavour to discuss the improvement of ECEC in Greece.

Table 1. Quality criteria in ECEC

\begin{tabular}{lll}
\hline UNICEF 2008 & ECNC \& EU recommendations \\
\hline Policy framework & $\begin{array}{l}\text { Parental leave of a year, on } \\
\text { half pay }\end{array}$ & \\
\hline COMMISSION'S RECOMMENDATION Investing in children: breaking the cycle \\
of disadvantage 20 February 2013 (2013/112/EU) \\
$\begin{array}{l}\text { National planning with } \\
\text { priority given to non- } \\
\text { privileged social categories }\end{array}$ & $\begin{array}{l}\text { Reduction of inequalities with investment in ECEC. } \\
\text { Further development of social integration and the potential for the development of } \\
\text { early childhood education and care (ECEC), using it as social investment for } \\
\text { confronting the challenges faced by non-privileged children through timely } \\
\text { intervention }\end{array}$ \\
\hline
\end{tabular}

\begin{tabular}{|c|c|c|}
\hline & Access & \\
\hline 3 & $\begin{array}{l}\text { Subsidized care services for } \\
25 \% \text { of children under } 3\end{array}$ & At least $33 \%$ of children under 3 should be provided with a nursery school place \\
\hline \multirow[t]{2}{*}{4} & $\begin{array}{l}\text { Subsidized early childhood } \\
\text { education services for } 80 \% \\
\text { of children from } 4 \text { years old } \\
\end{array}$ & $\begin{array}{l}\text { At least } 95 \% \text { of children from the age of } 4 \text { until the start of compulsory (primary) } \\
\text { education should participate in early childhood education }\end{array}$ \\
\hline & Quality & \\
\hline 5 & $\begin{array}{l}80 \% \text { of the staff working in } \\
\text { ECEC should have special } \\
\text { training }\end{array}$ & \multirow{2}{*}{$\begin{array}{l}\text { Maximization of the professional training of staff working in ECEC } \\
\text { Initial training, continuous education and continuous professional development, } \\
\text { corresponding to that of primary school teachers } \\
\text { The specialized staff should receive the same salary as teachers } \\
20 \% \text { of the staff should be men (see, Note) }\end{array}$} \\
\hline 6 & $\begin{array}{l}50 \% \text { of the staff working in } \\
\text { ECEC should be educated } \\
\text { to tertiary level }\end{array}$ & \\
\hline 7 & $\begin{array}{l}\text { The staff/child ratio should } \\
\text { not exceed } 1: 15 \\
\text { "in a safe, coherent, } \\
\text { sensitive, encouraging and } \\
\text { rewarding environment" } \\
\text { (page } 23 \text { ) }\end{array}$ & $\begin{array}{l}1: 4 \text { for children under } 12 \text { months } \\
1: 6 \text { for children aged } 12-23 \text { months } \\
\text { 1:8 for children aged } 24-35 \text { months } \\
\mathbf{1 : 1 5} \text { for children aged } 36-71 \text { months }\end{array}$ \\
\hline 8 & $\begin{array}{l}1 \% \text { of GDP (Gross } \\
\text { Domestic Product) to be } \\
\text { invested in ECEC }\end{array}$ & $\begin{array}{l}\text { Public funding for services for small children should not be less than 1\% of GDP, } \\
\text { so that the targets may be met } \\
\text { At least } 5 \% \text { of the above amount is available for support and advisory services } \\
\text { including continuous or in-service training and at least } 1 \% \text { for research and monitoring } \\
\text { There should be a funding programme for the construction of buildings and } \\
\text { renovations which are linked to environment and health targets } \\
\text { When parents pay for public ECEC services, the expenses should not exceed } 15 \% \text { of } \\
\text { the net monthly income of the householders or the amount should be still smaller }\end{array}$ \\
\hline
\end{tabular}




\begin{tabular}{lll}
\hline $\begin{array}{l}\text { Child poverty should be } \\
\text { below } 10 \%\end{array}$ & $\begin{array}{l}\text { RECOMMENDATION OF THE COMMISSION Investing in children: breaking the } \\
\text { cycle of disadvantage 20 February 2013 (2013,112/EU) } \\
\text { "Reduce inequality at the young ages by investing in ECEC" }\end{array}$ \\
\hline & $\begin{array}{l}\text { RECOMMENDATION OF THE COMMISSION Investing in children: breaking the } \\
\text { cycle of disadvantage 20 February 2013 (2013/112/EU) } \\
\text { Develop the correspondence of health systems to the needs of children from } \\
\text { disadvantaged environments } \\
\text { Improve support for the family and the quality of frameworks for care provision }\end{array}$ \\
\hline
\end{tabular}

The present survey focuses then on the access and quality indicators for ECEC in Greece and our fundamental aim is to provoke debate amongst all the interested parties for the setting out of a common plan/design for the improvement of ECEC in Greece.

\section{ECEC in Greece}

What is the state of ECEC in Greece, however, and how is this dealt with by the international community?

On $25^{\text {th }}$ October, 2013, László Andor, the Commissioner responsible for Employment, Social Affairs and Inclusion, in reply to the ND-EPP MEP George Papanikolaou, stated that: Greece has not met any of the Barcelona targets for child care.

A few months later, in the context of the Greek Presidency, the Ministry of Education and Religions organized a Conference in Athens (June 2014) on the issue "Early Childhood Education and Care: More Quality for all'. The state of ECEC in Greece was barely discussed at all, either formally or informally, during the conference, despite the fact that one would have expected it to be the focal point. In spite of this, and at the risk of being characterised as having utopian optimism, we will express our hopes and our wishes that the findings of the Conference, as they are laid out in the "Proposal for a Quality Framework on ECEC: Report of the ET2020 Thematic Working Group on ECEC under the auspices of the European Commission" (June 2014) which was adopted by the delegates, will form the basis of substantial improvement of ECEC in our country.

In this report we will not be concerned with the indicators regarding the policy framework and the support environment but, rather, we will focus on the indicators related to access and quality.

\section{Indicators related to access to ECEC in Greece}

\section{Indicator 3: Subsidized care services for 33\% of children under 3}

Evidence from several studies illustrate the importance of providing ECEC to children under 3 years old (Paxson\&Schady, 2007). But, with reference to the subsidized care services for 33\% 
of children under 3, Greece seems to be far from meeting the target. More precisely, the European Commission (2009: 12) states that:

All the European countries have established ECEC services but in some countries (the Czech Republic, Greece, Ireland, the Netherlands, Poland, the United Kingdom and Lichtenstein) there is extremely limited or no provision at all for public funding for children under the age of 3 and the participation rate in subsidized settings is very low.

More specifically, according to the most recent evidence concerning 2011, in Greece roughly $19 \%$ of children under the age of three are registered with a formal care provider in 2011 (EE-28 average 30\%) (Eurydice Report, 2014: 65).

In its report (April 2014) UNICEF (2014:79) states:

(In Greece) there are certain problems related to the operation (of nursery schools and kindergartens), such as a lack of staff, the suitability of the infrastructure and equipment, the imposition of subsistence fees, exceeding the foreseen ratio of nursery/kindergarten teachers and children and so on. The greatest problem, however, of a broader nature, which was observed, is that the existing low-cost structures (chiefly public ones) are not sufficient to meet the needs of all the children, and as a result many families are forced to turn to private nursery schools, which means additional financial cost, or their children are not integrated at all into a service of this kind. The provision of free nursery care services through the relevant actions of the N.S.R.F. in recent years, while judged to be of critical importance, is not enough to cover the needs of the entire population.

In addition, UNICEF's reference report $(2014: 80,81)$ continues

As emerges from statistical data, the percentage of children from the age of 3 until the start of compulsory (primary) education that do not receive formal care is consistently greater in Greece in comparison with Eurozone countries and in fact in 2008 reached $45 \%$ of this child population, while in the Eurozone countries it ranges consistently at about $10 \%$. Similarly, the percentage of children from the age of 3 until the start of compulsory (primary) education who receive formal care for more than 30 hours, is consistently smaller in Greece in relation to the Eurozone countries in which half the children receive corresponding care

\section{Indicator 4: At least 95\% of children from the age of 4 until the start of compulsory (primary) education should participate in early childhood education}

With reference to this indicator, the European Commission Commissioner for Education, AndroullaVasileiou, in reply to the MEP George Papanikolaou (ND-EPP) on 7/6/2013 mentioned that "The percentage in Greece is 73.5\% (2010 data)" (Vasileiou, 2013), while for 2011 it reaches 74.6\% (Eurydice Report: 2014: 62). The average for the European Union of 28 countries is however $93 \%$ (op. cit: 61 ).

In another source (European Commission/EACEA/Eurydice, 2013a), the relevant data provided for Greece (2011) are slightly differentiated and more precisely $76 \%$ is mentioned (with the average in the 27 countries of Europe being 93.2\%). 
Given that early childhood education is only compulsory for one year [the establishment of attendance at nursery school for children aged 5-6 as compulsory (Law 3518, article 73, GG 272 t. A', 21.12.2006) is a relatively recent achievement and the outcome of many battles and claims], from the above data it is not clear how many four-year-olds are excluded due to the fact that the available places are taken by the five-year-olds. The Eurydice Report (2014: 170) states that $54.3 \%$ of four-year-olds in Greece participate in early childhood education [European average for four-year-olds: $83 \%(\mathrm{OECD}, 2012 \mathrm{~b})]$, while for five-year-olds the corresponding participation reaches $95.6 \%$. These numbers reveal that a note worthily large percentage of children don't attend two years of early childhood education. The issue of the demand for and establishment of compulsory attendance for four-year-olds too proves to be even more important, if we bear in mind that in the PISA contest (OECD, 2012b) the children that had attended early childhood education did better than those who hadn't and for this reason the Organization for Economic Cooperation and Development as much as the European Union propose universal access of children from four years of age to early childhood education. It is worth noting here that OECD (2012a: 74) proposes, besides longer attendance in early childhood education, a reduction in the child-staff ratio and higher public investment per child so as to ensure the best possible quality ECEC provision.

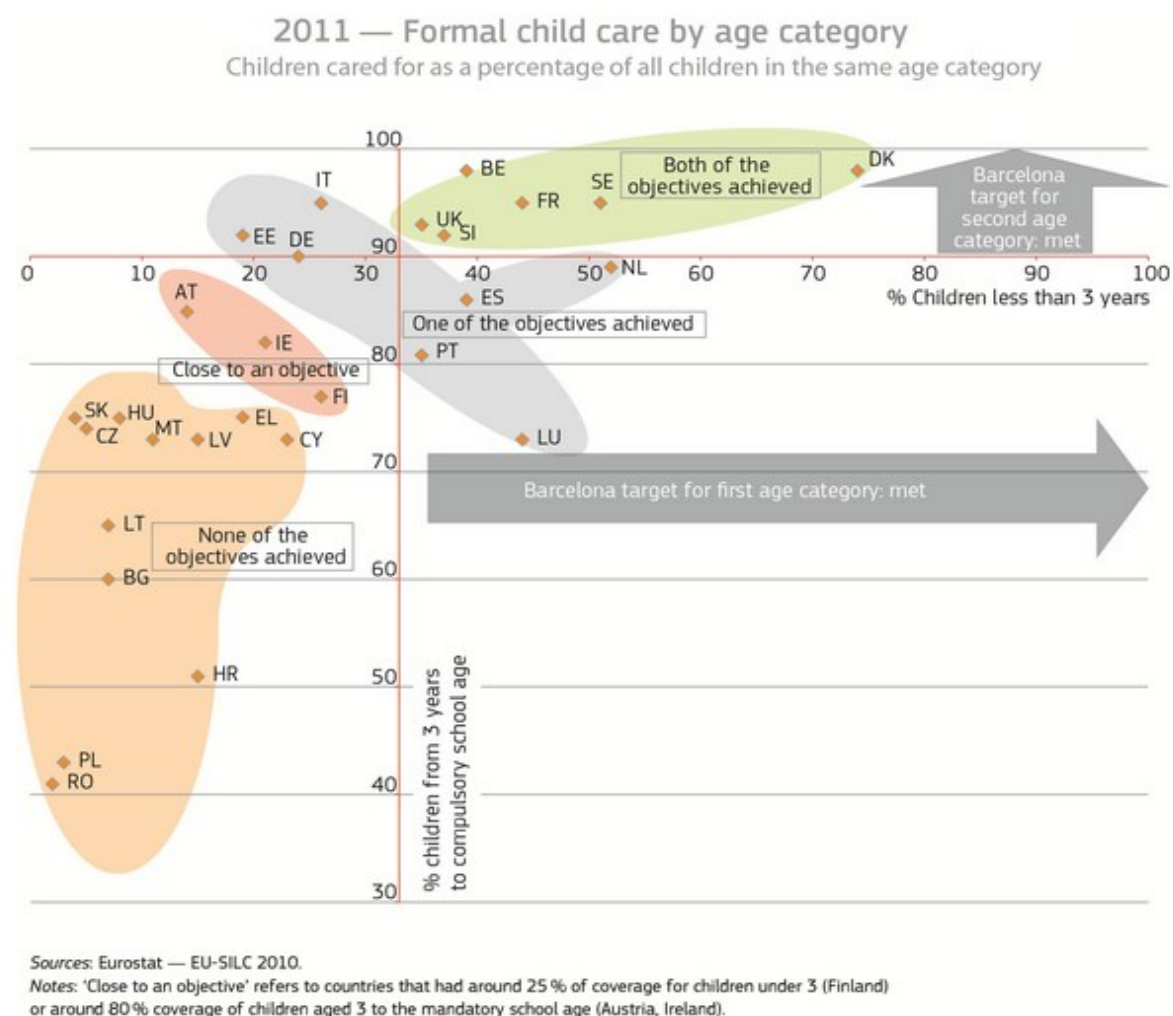

Figure 1. Greece among the countries that haven't met any of the European targets related to access to $E C E C$ 
The graph (retrieved from the "European Commission Report on childcare provision in the Member States and study on the gender pension gap" $)^{1}$ confirms and verifies what has already been said. One can then conclude, admittedly with excessive disappointment, that Greece unfortunately- is among the countries that hasn't met either of the two targets regarding children's access to and their participation in early childhood education. Although it is comforting that in January 2018 the Parliament voted for the progressive inclusion of all 4 years old children to free of charge public preschool system.

\section{Indicators regarding the quality of ECEC in Greece}

\section{Indicators 5 \& 6: Professional training of nursery and kindergarten teachers}

This indicator is the only one that, at least numerically, is in line with the target, which is the tertiary or university education of those who work in early childhood education. As is apparent in the Figure 2 that follows (European Commission/EACEA/Eurydice, 2013b: 26), those employed in ECEC in Greece are tertiary education graduates, which means that they are graduated from Universities after attending four years program in which practicum is included (see also Eurydice Report, 2014: 99).

However:

a) The indicators should be seen as interrelated, interconnected and interdependent factors. Quality cannot be achieved without the fulfilment of all targets.

b) Among other things, the initial training (e.g. students' teaching practice), the continuing education of active nursery and kindergarten teachers (for more, see: CoRe, 2011), the lack of support from specialised staff (e.g. psychologists, speech therapists, work therapists) and the bureaucratic load on the shoulders of the nursery heads, are worrying. As noted by Vandekerckhove \& Peeters (2016), "guaranteeing quality demands a qualified workforce, in terms of not only initial training but also continuous professional development, with a balance between theory and practice", while Ionescu, Josephson \& Neuman (2016) underpin the importance of the teachers' appropriate training, monitoring and mentoring, good recognition of their profession and decent working conditions.

\footnotetext{
1 3/6/2013: http://europa.eu/rapid/press-release_MEMO-13-490_en.htm 
- Figure A2a: Level and minimum length of initial teacher education of pre-primary and primary

teachers, and the minimum proportion of time spent on professional training, 2011/12 Pre-primary teachers (ISCED 0)

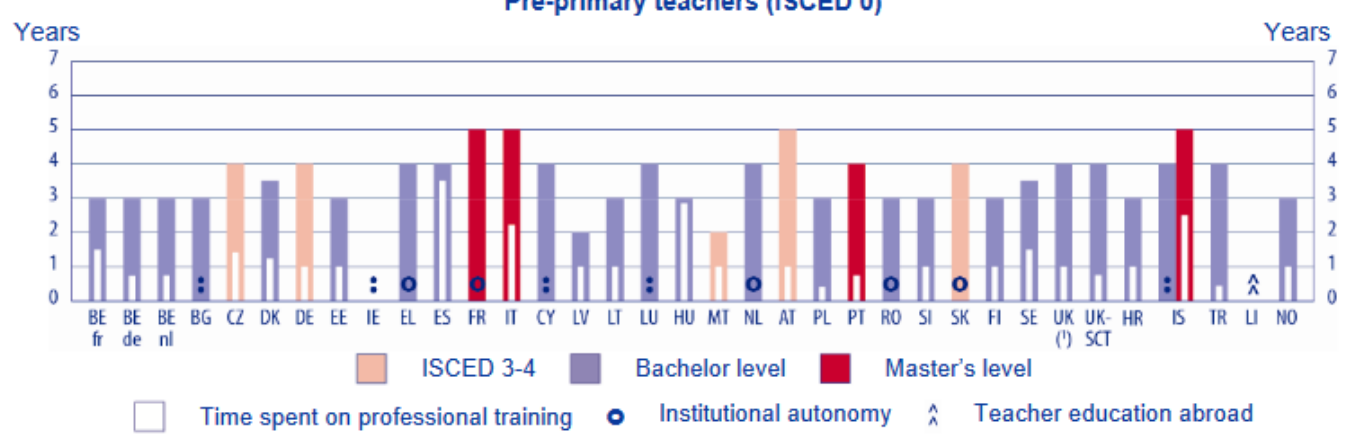

Time spent on professional training (\%)

\begin{tabular}{|c|c|c|c|c|c|c|c|c|c|c|c|c|c|c|c|c|c|}
\hline$B E \mathrm{fr}$ & BE de & $\mathrm{BE} \mathrm{nl}$ & BG & $C Z$ & DK & $\mathrm{DE}$ & EE & IE & EL & ES & FR & IT & CY & LV & LT & LU & HU \\
\hline 50 & 24.4 & 25 & & 35.4 & 35.2 & 25 & 33.3 & : & 0 & 87.5 & 0 & 44.3 & & 50 & 33.3 & : & 95 \\
\hline MT & NL & AT & PL & PT & RO & SI & SK & FI & SE & UK (1) & UK-SCT & HR & IS & IS & TR & 니 & NO \\
\hline 50 & 0 & 20 & 13.8 & 18.8 & 0 & 33.3 & 0 & 33.3 & 42.9 & 25 & 19 & 33.3 & : & 50 & 11 & $\hat{\imath}$ & 33.3 \\
\hline
\end{tabular}

Figure 2. The initial training of ECEC teachers

\section{Indicator 7a: Staff/child ratio 1:15 (for nursery school)}

One of the factors that the Council of the European Commission links to high quality ECEC is the child/staff ratio: More precisely, it is recognised that "participation in high quality ECEC, with highly specialized staff and a suitable child-staff ratio, produces positive results for all the children and has greater benefits for the more disadvantaged" (Council of the EC, 2010:5). Furthermore, the Organization for Economic Cooperation and Development finds that "research shows that the ratio 1:15 in nursery schools is the highest limit for children under five years of age [...] and that for more individualised attention, lower ratios are more suitable" (OECD, 2004:59).

This ratio has been adopted and is recommended as the highest desirable by other international organizations such as Education International (2010) and the National Association for the Education of Young Children (NAEYC: 2005), while at the same time it is the target that the Teaching Union of Greece aspire to (745/15-2-2012).

Likewise, the International Labour Organization (2013: 40) seems to be even more demanding regarding this indicator, recommending a staff/child ratio of 1:10 and 20 as the highest number of children per nursery class, with two teachers. Once again, however, in contrast to the above, one finds that in Greece the situation is determined differently:

a) "The number of infants per nursery teacher is set at 25 infants" (JMD, 2006) 
b) "In exceptional circumstances, the number of pupils in primary schools and infants in the infants' schools can, with a decision by the appropriate Director of Primary Education, exceed the pupil per teacher and infants per infant teacher ratio by $10 \%$, as this is laid down in the above JMD" (JMD, 2013)

Bearing in mind relevant research which notes that the teacher/child ratio is related as much to the learning outcomes (OECD: Starting Strong III, 2012: 18), since it permits the individualized attention and more frequent interaction (NAEYC, 2005), as to safety, since the teacher has to look after a smaller number of children, one understands that the relevant provisions that are valid in Greece should be subject to immediate review.

Indicator 7b: An environment which is safe, encouraging, rich in stimuli and potential for play and investigation

The answer that could be given to the question posed by teachers, parents, scientists and others regarding which environment could be considered "safe, encouraging and rich" could be found in Targets 30-32 which are included in the European Network on Childcare (1996: 33). More precisely, the following are recommended:

"Internal space of at least 6 square meters for each child under three years and of at least 4 square meters for each child

3-6 years (excluding corridor and storage or through-way space)

“...direct access to external space of at least 6 square meters per child"

“... an additional $5 \%$ of internal space for adult use.”

Naturally, as with the previous indicators, in Greece the provision is for 2 square meters of internal space per child (Presidential Decree 71/1988 \& Ministerial Decision 8185/2474/1991 - Government Gazette 360, V. A').

Regarding this issue, the Greek Committee of the World Organization for Early Childhood Education (OMEP) noted in a resolution in 2008:

The significant shortages in the spaces of the infant schools, besides the problems of safety and health, make difficult, if not inhibit, the pedagogical work that the infant teachers are called on to perform, and they downgrade the contribution and the role of early childhood education.

In addition, the Commissioner for the Rights of the Child (2012: 16) notes:

A number of schools in Greece continue to be housed in old buildings, in prefabricated classrooms ('containers') or to offer inadequate playgrounds, with negative consequences for the quality of the education provided and the safety of the pupils. 
Recently operational problems have also been noted due to the lack or delay of funding, something which leads from time to time to serious shortages in maintenance, heating and in the supply of essential expendable goods.

We could conclude that there seems to be a great divergence between, on the one hand, what is foreseen and recommended regarding this indicator and, on the other hand, the existing structures in the Greek schools. The building infrastructure of the contemporary nursery schools cannot be considered satisfactory (ind.Vrinas, 2010). The provisions of the School Buildings Organization (SBO, 2008) are not implemented in practice, except in a very few cases, and the general picture of many nursery schools can only be described as sad and dangerous for the safety of the children.

\section{Indicator 8: 1\% of GDP (Gross Domestic Product) is invested in ECEC}

Data from different organisations and surveys confirm that early childhood is currently underfinanced and many countries spend less on pre-primary than on primary education (McCuaig, Akbari \& Bertrand, 2016; Putcha, Upadhyay\& Burnett, 2016). Although, as it is shown in the following graph, western Europe countries' expenditure on pre-primary education approaches the number of $0.4 \%$ of GDP on average.
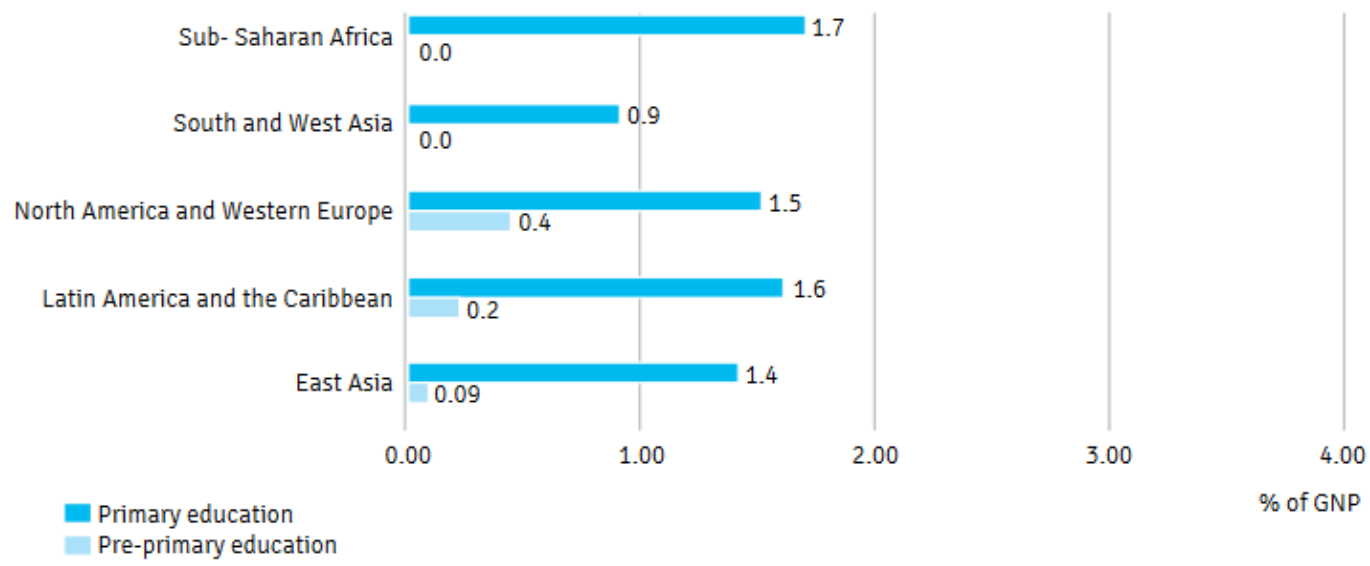

SOurce: UNESCO

Figure 3.Public expenditure on pre-primary and primary education as a percentage of GDP by region, 2012 (UNESCO, 2015)

Given the above, one would expect that Greece approaches the average spending on ECEC of the other EU countries. But, once again, this does not happen. In a related question (E-00468513) on $26^{\text {th }}$ April 2013 on the "comparative level of public spending on early childhood education amongst member states", George Papanikolaou, MEP ND-PPE, received from the Commissioner for Education of the EC, Ms AndroullaVasileiou, the following answer: "Data 
for Greece has not been updated in recent years". Indeed, in the Commissioner's reference ${ }^{1}$ the fact is noted that Greece hasn't sent data since 2004. Simultaneously, Greece appeared to diverge significantly from all the other groups of nations and, indeed, showed a decrease between 2002 and 2004 in contrast to all the other groups.

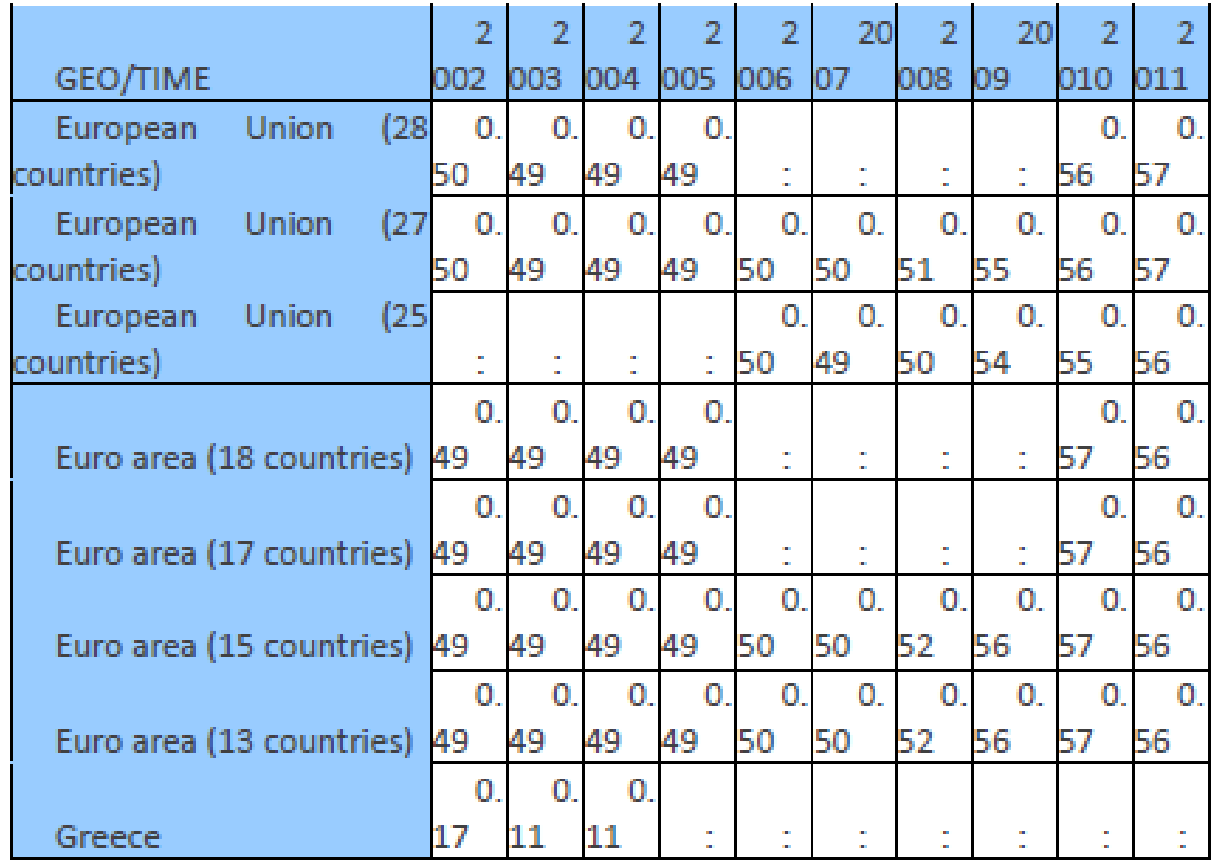

Figure 4.Eurostat: Public investment in early childhood education (ISCED 0)

In the more recent survey (Eurydice Report, 2014: 80), Greece is the only country for which relevant data is not recorded.

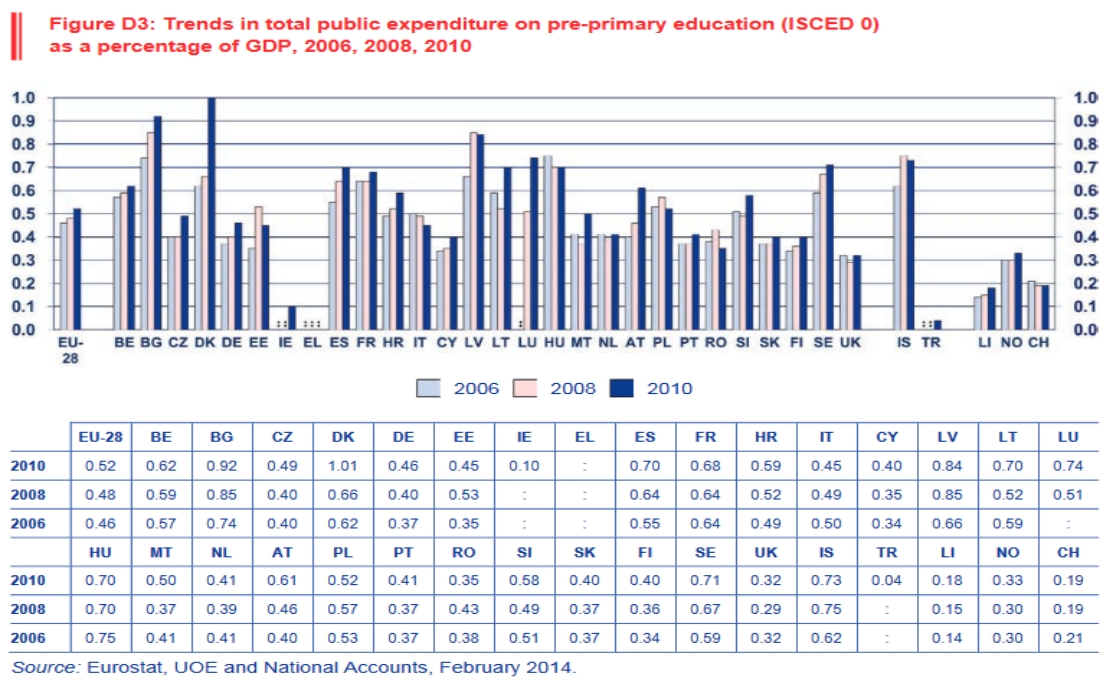

Figure 5.Eurydice 2014

\footnotetext{
${ }^{1}$ http://appsso.eurostat.ec.europa.eu/nui/submitViewTableAction.do;jsessionid=9ea7d07e30d89eb2ffd185bb4 c478847d830f3057473_e340aN8Pc3mMc40Lc3aMaNyTbxOPe0 
Furthermore, the Education Department of the then (2012) opposition party verified the reasons for the non-updating of data on the part of the Greek political leadership, claiming in an announcement on 12.11.2012 how in the budget for 2013 total spending on education amounted to $2.51 \%$ and for ECEC less than $\mathbf{0 . 1 \%}$ of GDP. If this is true, it is apparent that Greece has the smallest spending on ECEC out of all the member states of the European Union, approaching the average of developing countries worldwide (0,07\%) (UNESCO, 2015).

So, a reasonable question arises:

Why, in contrast to other recommendations of the European or International Organizations, are the recommendations for quality ECEC not respected, or indeed given priority, by the Greek government, since it has been proved that "the benefits of a high quality ECEC are on a broad scale: socially, economically, and educationally.’[COM (2011) 66: 17.2.2011]?

\section{DISCUSSION}

We believe that civilization, the quality of its accomplishments and the vision of a society for its future, which is none other than its small citizens, is reflected with the greatest possible clarity in the nursery schools. We refuse to accept that the condition of the nursery schools as it is today in Greece is an expression of the passion, the visions and the desires of its citizens. On the contrary, we believe that it is "one of the most fundamental structural causes of the crisis we are experiencing today" (Arvanitopoulos, former Education Minister, 8.5.2014) and, for this reason, if it is given the priority it deserves, it will contribute to a way out of the crisis, ensuring social cohesion, sustainable and just social growth, while at the same time it will ensure the best possible start for ALL the children who live in our country.

“The real measure of a country's position is how well it takes care of its children: of their health and safety, of their material safety, their education and their socialization and the feeling that they are loved and valued by their families and the societies they live in" (UNICEF, 2007: 1).

Who can disagree that "the future belongs to those countries that invest wisely in their children, while failure to do so undermines social and economic progress? The development of children is the cornerstone of every development" (USA Government Action Plan on Children in Adversity (2012: 1).

A robust fund of research has proven that high quality preschool education is effective in supporting all young children and especially those who grow up in less privileged environments, belong to marginalised groups, or live in vulnerable conditions. If we consider this issue from the perspective of the Rights of the Child then it is clear that it is duty of the 
government to give them every opportunity possible to succeed in education, and the foundational stage for this is ECEC.

We hope that to our voice and to our effort will be added many more still, which will make what is taken for granted, at least in European countries, a reality in Greece. For our children, for the citizens of tomorrow, for our future.

\section{Limitations}

The present report focused on access to and quality of ECEC in Greece and particularly in infant schools. Unfortunately, it wasn't possible to find analytical data regarding nursery schools. In addition, data regarding the support of families (e.g. parental leave), children's health, children in danger of poverty or exclusion [the percentage of which is 33.2\% (Eurydice Report, 2014: 17) significantly higher than the EU average], the falling birth rate [where Greece again appears in the group of countries that is especially affected (Eurydice Report, 2014: 23], the youth unemployment rate and immigration are not included. These indicators, together with those referred to here, should be cause for reflection and should mobilize us, so as to fight to provide our children with the best possible start in life.

\section{Proposals}

The measures that should be taken and the changes that should be noted could, to a great extent, be characterised as ground-breaking but not utopian, in order to accomplish the goal which is none other than the improvement of access to and quality of ECEC in the folds of Greek society.

To start with, the Greek Government and the authorities should mobilize themselves, publishing the relevant data for ECEC in Greece.

In addition, the Greek government should, bearing in mind the disappointing data to date, lead an effective discussion on the formation of a realistic strategic plan for Early Childhood Education and Care, so that it can meet the social needs and come into line with the recommendations of the International Bodies and the commitments it has taken on in the EU. In this dialogue, the presence and active participation of representatives of the academic workforce of the country, teacher and parent organizations, as well as representatives from international scientific organizations, is seen as imperative. And this is so since the utilization of their socio-cultural features, with whatever convergences and divergences exist between them, can contribute to the maximum to the design and organization, not only of far-reaching but realistic and immediately applicable action strategies for the improvement of ECEC in our country. 
The inhomogeneity of the student population (socio-cultural, economic, educational, etc) should be taken into serious consideration in this planning, as should their co-existence at the micro-level of the school classrooms, so that children from vulnerable social groups are given priority to provision.

The interested parties should bring the importance of ECEC to the all-rounded development of the child (as is claimed in all the European early childhood education curricula), social justice and sustainable development, to the forefront of public debate.

In particular, as seen in the context of the current economic situation, investment in ECEC should be promoted by the interested parties as something which is not only socially just, but as something which has multiple short and long term benefits (ind.Naudeau, Kataoka, Valerio, Neuman\& Elder, 2011), which make it one of the wisest and most financially profitable investments (see Calman\&Tarr-Whelan, 2005). The words of Nobel laureate in economics (2000) James Heckman are absolutely in line with the above position: "Timely investment in early childhood allows us to shape the future. Investment later simply forces us to correct the lost opportunities of the past" (Heckman, 2011).

Note:The increase in the number of men working in ECEC is expressly referred to in the recommendations of the Committee of the Permanent Representatives to the Council of Europe (Brussels, $6^{\text {th }}$ May 2011, 9424/11: http://register.consilium.europa.eu/doc/srv?l=EL\&f=ST\%209424\%202011\%20INIT)

\section{REFERENCES}

Albright, A., Mundy, K., \& Beardmore, S. (2016). The global partnership for education 20162020: enhancing early childhood care and education. In J. Lombardi (Ed.), Early Childhood Matters: Advances in early childhood development, 22-25. Hague, Netherlands: Bernard van Leer Foundation.

Andor, L. (2013). Commissioner for Employment, Social Affairs and Inclusion. Answer given on behalf of the Commission to the question posed by Georgios Papanikolaou, ND-EPP minister on 25th October 2013 - E-009977/2013. Retrieved from: http://www.europarl.europa.eu/sides/getAllAnswers.do?reference=E-2013009977\&language $=$ EL\#ref2

Calman, L. \& Tarr-Whelan, L. (2005). Early Childhood Education for All: A Wise Investment. New York, NY: Legal Momentum. 
Commissioner for the Rights of the Child (2012). Report to the UN committee on the rights of the child. Findings and proposals of the independent authority for the implementation of the rights of the child in Greece (July 2003-December 2011). Retrieved from: http://www.synigoros.gr/resources/docs/ek8esh-pros-thn-epitroph-dikaiwmatwn-toypaidioy-toy-ohe.pdf

CoRe: Competence Requirements in Early Childhood Education and Care. (2011). London: University of East London \& University of Ghent.

Council of Europe (2010). Council Conclusions of 11 May 2010 on the social dimension of education and training. Official Journal of the European Union, C135/ 26.5.2010

Council of the EU (2006). Draft Conclusions of the Council and the Representatives of the Governments of the Member States, meeting within the Council, on efficiency and equity in education and training (2006/C 298/03). Retrieved from: http://eurlex.europa.eu/legal-content/EL/TXT/?uri=uriserv:OJ.C_.2006.298.01.0003.01.ELL

Council of the EU (2011). Council Conclusions on early childhood education and care: providing all our children with the best start for the world of tomorrow (2011/C 175/03). Official Journal of the European Union, 15.6.2011: C 175/8.

Education International (2010). Early Childhood Education: A Global Scenario. Brussels: Education International.

European Commission/EACEA/Eurydice (2013a). Education and Training in Europe 2020: Responses from the EU Member States. Eurydice Report. Brussels: Eurydice.

European Commission/EACEA/Eurydice (2013b). Key Data on Teachers and School Leaders in Europe. 2013 Edition. Eurydice Report. Luxembourg: Publications Office of the European Union. doi:10.2797/91785

European Council (2009). Tackling Social and Cultural Inequalities through Early Childhood Education and Care in Europe. Education, Audiovisual and Culture Executive Agency. P9 Eurydice. Retrieved from: http://eacea.ec.europa.eu/about/eurydice/documents/098EN.pdf. DOI 10.2797/18055.

European Council (2011). Early childhood Education and Care. Providing all our children with the best start for the world of tomorrow [COM (2011) 66] Retrieved from: http://eurlex.europa.eu/LexUriServ/LexUriServ.do?uri=COM:2011:0066:FIN:EL:PDF

Eurydice Report (2014). Key Data on Early Childhood Education and Care in Europe. Brussels: Education, Audiovisual and Culture Executive Agency. doi:10.2797/75270

General Comment No. 7 (2005). UN Committee on the Rights of the Child on implementing child rights in early childhood. Geneva: UN.

Gertler, P., Heckman, J., Pinto, R., Zanolini, A., Vermeersch, C., Walker, S., Chang, S.M. \& Grantham-McGregor, S. (2014). Labor market returns to an early childhood stimulation intervention in Jamaica. Science, 344(6187), 998-1001. DOI: 10.1126/science.1251178 
Heckman, J. (2011). The Economics of Inequality: The Value of Early Childhood Education. American Educator, Spring 2011,31-47.

ILO (2013). Policy guidelines on the promotion of decent work for early childhood education personnel. Geneva: ILO.

Ionescu, M., Josephson, K., \& Neuman, M. (2016). The Early Childhood Workforce - a powerful force for scaling-up quality services for young children and their families. In J. Lombardi (Ed.), Early Childhood Matters: Advances in early childhood development, 46-51. Hague, Netherlands: Bernard van Leer Foundation.

JMD (2006). F.3/989/97657/G1: Number of Infants per class in Infant Schools. GG 1507, tB/13-10-2006, pp. 20147-8.

JMD (2013). Modification-Supplementation of Joint Ministerial Decisions F.3/897/97652/G1/25-9-2006 and F.3/898/97657/G1/25-9-2006 (GG 1507, t. B'/13-102006).

Lake, A. (2016). Applying the science: how what we are learning about brain development should shape policies, practical action, and public advocacy. In J. Lombardi (Ed.), Early Childhood Matters: Advances in early childhood development, 12-15. Hague, Netherlands: Bernard van Leer Foundation.

McCuaig, K., Akbari, E., \& Bertrand, J. (2016). The Role of Public Policies in Promoting Equity in Early Childhood. In The Consultative Group on Early Childhood Care and Development, Global report on equity and early childhood, 30-50. Leiden, Netherlands: The Consultative Group on Early Childhood Care and Development.

National Association for the Education of Young Children (NAEYC) (2005). Early Childhood Program Standards and Accreditation Criteria: The Mark of Quality in Early Childhood Education. Washington, DC: NAEYC.

National Scientific Council on the Developing Child (2007). The Science of Early Childhood Development: Closing the Gap Between What We Know and What We Do. Cambridge, Mass.: Author. Retrieved from: http://developingchild.harvard.edu/wpcontent/uploads/2015/05/Science_Early_Childhood_Development.pdf

Naudeau, S., Kataoka, N., Valerio, A., Neuman, M. J. \& Elder, L. K. (2011). Investing in young children: An early childhood development guide for policy dialogue and project preparation. Washington, DC: The World Bank.

OECD (2001). Starting Strong: Early Childhood Education and Care. Paris: OECD.

OECD (2004). Canada: Country Note. Paris: Directorate for Education, OECD. Retrieved from: http://www.oecd.org/canada/33850725.pdf

OECD (2006). Starting Strong II: Early Childhood Education and Care. Paris: OECD.

OECD (2010). PISA 2009 Results: Executive Summary. Paris: OECD. Retrieved from:. http://www.oecd.org/pisa/pisaproducts/46619703.pdf 
OECD (2012a). Access to early childhood education. In Education at a Glance 2012: Highlights. Paris: OECD.

OECD (2012b). Starting Strong III: A Quality Toolbox for Early Childhood Education and Care. Paris: OECD.

OMEP (2012). Open Appeal to Local, National, Regional and Global Leaders. Secure the World's Future: Prioritize Early Childhood Development, Education, and Care.

Paxson, C. \& Schady, N. (2007). Cognitive development among young children in Ecuador: the roles of wealth, health, and parenting. Journal of Human Resources, 42 (1), 49-84.

Penn, H. (2009). EARLY CHILDHOOD EDUCATION AND CARE: Key lessons from research for policy makers. An independent report submitted to the European Commission by the NESSE networks of experts. European Commission. Retrieved from: http://www.nesse.fr/nesse/activities/reports

Proposal for a Quality Framework on ECEC: Report of the ET2020 Thematic Working Group on ECEC under the auspices of the European Commission (2014). Brussels: Eurydice.

Proulx, K., \& Lye, S. (2016). Equity in early childhood development: A global perspective. In The Consultative Group on Early Childhood Care and Development, Global report on equity and early childhood, 12-29. Leiden, Netherlands: The Consultative Group on Early Childhood Care and Development.

Putcha, V., Upadhyay, A., \& Burnett, N. (2016). A call for public financing: innovative finance is welcome, but not enough. In J. Lombardi (Ed.), Early Childhood Matters: Advances in early childhood development, 52-57. Hague, Netherlands: Bernard van Leer Foundation.

Raikes, A., \& Shaeffer, S. (2016). The global partnership for education 2016-2020: enhancing early childhood care and education. In The Consultative Group on Early Childhood Care and Development, Global report on equity and early childhood, 1-11. Leiden, Netherlands: The Consultative Group on Early Childhood Care and Development.

SBO (2008). Study Guide for School Buildings at all levels of education. Athens: SBO.

Sylva, K., Melhuish, E., Sammons, P., Siraj-Blatchford, I., \& Taggart, B. (Eds.). (2010). Early childhood matters: Evidence from the effective pre-school and primary education project. London-New York: Routledge.

UNESCO (2011). ISCED 2011 Operational Manual: Guidelines for Classifying National Educational Programmes and related qualifications. Paris: OECD Pub.

UNESCO (2015). Education for All Global Monitoring Report. Statistical Tables. Retrieved from: http://en.unesco.org/gem-report/node/6 (accessed March 2017)

UNICEF (2007). Child poverty in perspective: An overview of child well-being in rich countries. Innocenti Report Card 7, 2007. UNICEF Innocenti Research Centre, Florence. 
UNICEF (2012). Inequities in Early Childhood: What the Data Say. Evidence from the Multiple Indicator Cluster Surveys. New York: Author.

UNICEF (2014). The State of the Children in Greece Report 2014 - The repercussions of the economic crisis on children. Athens: UNICEF. Retrieved from: http://www.unicef.gr/uploads/filemanager/PDF/2014/children-in-greece-2014.pdf

United Nations (2015). Transforming our world: The 2030 agenda for sustainable development. Resolution adopted by the General Assembly on 25 September 2015. New York, NY: United Nations. Retrieved from: http://www.un.org/ga/search/view_doc.asp?symbol=A/RES/70/1\&Lang=E (accessed January 2017)

United States Government Action Plan on Children in Adversity. A Framework for International Assistance: 2012-2017. December 2012. Retrieved from: www.childreninadversity.gov/docs/defaultsource/default-documentlibrary/apca.pdf?sfvrsn=2

Van Belle, J. (2016). Early Childhood Education and Care (ECEC) and its long-term effects on educational and labour market outcomes. Santa Monica, CA: RAND Corporation. Retrieved from: http://www.rand.org/pubs/research_reports/RR1667.html. DOI: $10.7249 / \mathrm{RR} 1667$

Vandekerckhove, A., \& Peeters, J. (2016). Transatlantic Forum on Inclusive Early Years: a dialogue on high-quality ECEC for all. In J. Lombardi (Ed.), Early Childhood Matters: Advances in early childhood development, 81-82. Hague, Netherlands: Bernard van Leer Foundation.

Vasileou, A (2013). Answer to minister Georgios Papanikolaou (ND-EPPP 7th June 2013 (E004685/2013) Subject: Investments in ECEC. Retrieved from: http://www.europarl.europa.eu/sides/getAllAnswers.do?reference=E-2013$004685 \&$ language $=\mathrm{EL}$

Vrinas, N. (2010). Investigation of risk factors in the causing of accidents in the school environment. Postgraduate thesis: Department of Medicine, University of Crete.

Working Group on Early Childhood Education and Care (2015). Proposal for Key Principles of a Quality Framework for Early Childhood Education and Care. Retrieved from: http://ec.europa.eu/education/policy/strategic-framework/archive/documents/ececquality-framework_en.pdf (accessed March 2017)

World Bank \& UNICEF (2016). World Bank Group, UNICEF urge greater investment in early childhood development. Press release, April 14. Retrieved from: http://www.worldbank.org/en/news/press-release/2016/04/14/world-bank-groupunicef-urge-greater-investment-in-early-childhood-development (accessed January 2017)

Yoshikawa, H., Weiland, C., Brooks-Gunn, J., Burchinal, M. R., Espinosa, L. M., Gormley, W. T., Ludwig, J., Magnuson, K., Phillips, D., \& Zaslow, M. J. (2013). Investing in Our Future: The Evidence Base on Preschool Education. Ann Arbor, Michigan/New York: 
Society for Research in Child Development (SRCD)/Foundation for Child Development (FCD).

\section{APPENDIX I}

UNICEF (2008). The child care transition: A league table of early childhood education and care in economically advanced countries. Report Card 8. Florence: UNICEF Innocenti Research Centre. (http://www.unicef-irc.org/publications/pdf/rc8_eng.pdf)

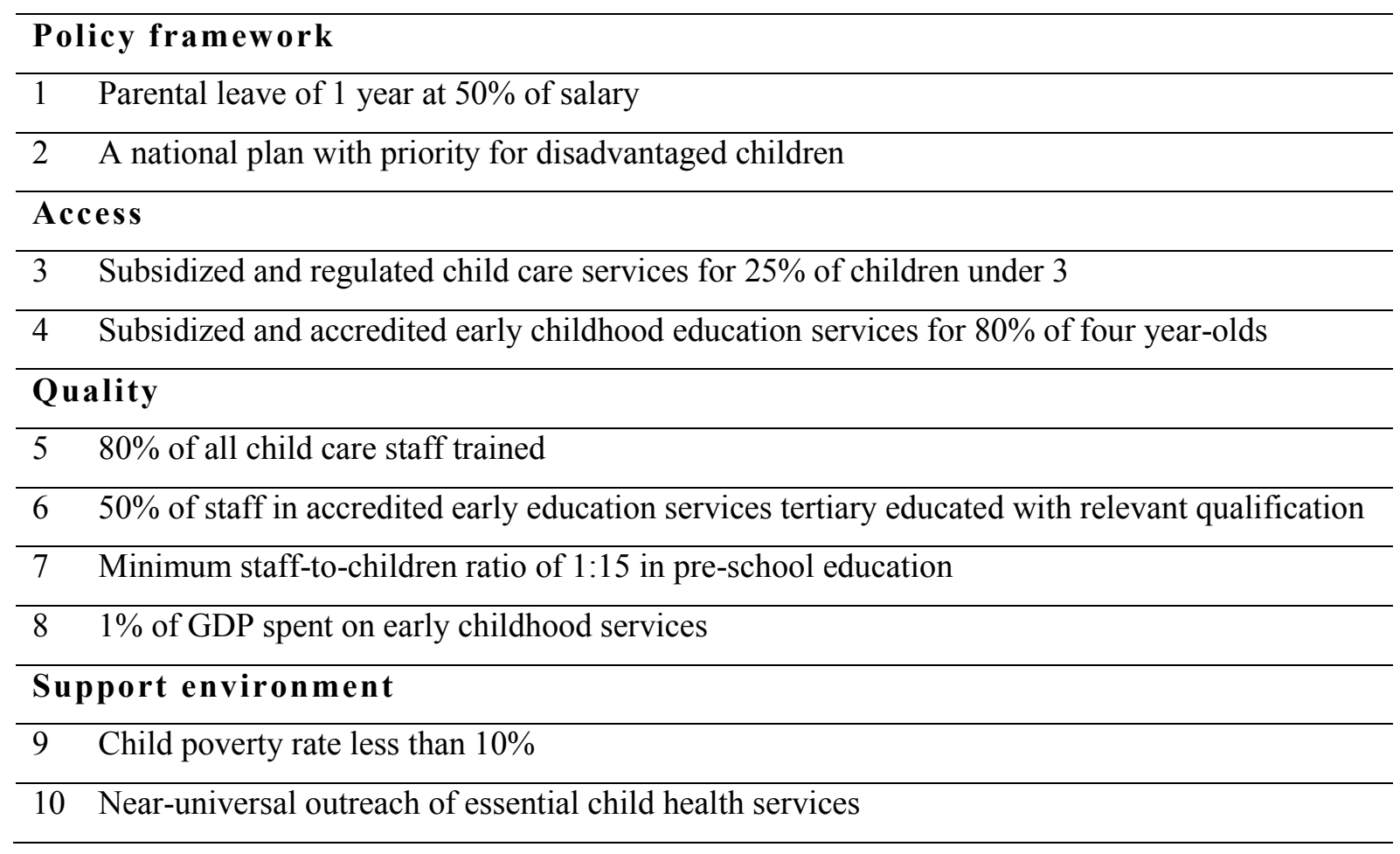

\section{APPENDIX II}

\section{Targets for the quality of services directed at small children (to 5 years old)}

These targets have been developed by the European Commission Network on Childcare and Other Measures to Reconcile the Employment and Family Responsibilities of Men and Women: Proposals for a Ten-Year Action Programme (1996), which can be found on the webpage: http://www.eurochild.org/fileadmin/user_upload/files/thematic_priorities/Yearly_years/EC_C hildcare_Network_Quality_Targets_in_Services_for_Young_Children_1996.pdf

In addition, it is included in the "Early Childhood Education and Care Services in the European Union Countries: Proceedings of the Child on Europe Seminar and Integrated review. (2010). IstitutodegliInnocenti di Firenze. (pages 81-84), which can be found on the webpage:http://www.childoneurope.org/issues/publications/ECEC_Report_rev.pdf 